\title{
English For Specific Purposes (Esp) To Improving Speaking Skill In Division Management (Rdm)
}

\author{
Syamsidah Lubis ${ }^{1}$ Dinn Wahyuddin ${ }^{2}$ Rusman $^{3}$ \\ \{syamsdhl@gmail.com ${ }^{1} d i n n \_w a h y u d i n . @ . u p i . e d u^{2}$ rusman_71@yahoo.com. $\left.{ }^{3}\right\}$ \\ Student Postgraduate in curriculum development, Universitas Pendidikan Indonesia, Street Dr. Setia \\ Budhi No 229, Bandung, 40154, Indonesial Head of PPG, Professor and Doctor in Curriculum \\ development ${ }^{2}$, Head of curriculum development study program, School Postgraduate ${ }^{3}$.
}

\begin{abstract}
The research aim to examine more deeply the effectiveness of English for Specific Purposes (ESP) to improving speaking skills in Room Division Management (RDM). The speaking skills of a Room Division Management (RDM) should be appropriate and specific. In this research, the problem is how the effectiveness tourism students to improving speaking skills. The method used is descriptive and quantitative approaches. There are 41 tourism students in Class Room Division Management (RDM). The results of the study show that with the English for Specific Purposes (ESP) students more effectiveness and it is easier to understand English subjects and to improving speaking skills. From statistical processing, it obtained an average value. Students have an average value of 83.95, the highest score of 90 , and the lowest score of 72 . So it can be concluded that student learning outcomes are very good, and meet the minimum completeness criteria (70) in learning. Furthermore, the study of English for Specific Purposes (ESP) needs to be studied in more depth for Tourism Study Program. Researchers limit this research only in terms of concepts and have not been given treatment to students. The results of the student's research scores are obtained from the lecturers' documents that teach English courses through the academic section. The main skills for Tourism Study Program students are speaking skills, and the material must be specific about tourism, making it easier for students in the world of work.
\end{abstract}

Keywords: English for Specific Purposes (ESP), Tourism, Speaking Skill

\section{Introduction}

The tourism industry is a fast growing industry in Indonesia. Therefore, the industry really needs Human Resources (HR) that are able to compete globally. Tourism Study Program in the industry is able to develop and promote tourism in the Batam. The government is very enthusiastic in promoting tourism in the Batam. Furthermore data from the Central Statistics Agency (BPS) released by the data and information center of the Ministry of Tourism and Creative Economy stated that the Indonesian tourism industry continues to show high growth in each year. Data at the end of 2012 the total number of foreign tourists visiting Indonesia was $8,044,462$ tourists, showing a $5 \%$ increase from the total number of tourists the previous year. This figure is equivalent to 9.07 billion in state revenue, and tourism as the non-oil industry sector is the highest foreign exchange earner in Indonesia (BPS: 2011). The growth of the tourism industry as the largest and fastest growing trade, service and investment industry sector. The progress and development of the tourism industry is determined by several factors. 
As stated Meeting, Incentive, Convention, Exhibition (MICE) is a type of activity in the tourism industry. Tourism activities between leisure and business, which usually involve a group of people, a series of activities in the form of meetings, incentive travels, conventions, congresses, conferences and exhibitions suggest that tourism determinants include: security, price, ease of access, facilities, infrastructure, supporting entertainment, and language.

English is an international language that has a very important role, namely as a means of communication, both verbal and nonverbal. In this globalization era, English has become the language of instruction in various fields of science. Therefore, English is one of the subjects for students as a communication tool. English should be mastered well in order to communicate well. Good mastery of English is something that is sought and learned so that it can use the language properly, fluently, and free to communicate with people who use English. Because the demands of English language skills are increasing, along with the progress of Science, Technology, Information, and Arts (IPTEKS), and other fields. Someone can more freely establish communication with other people who come from different nations with himself. English is also an important medium for developing and spurring economic growth, so English teaching is expected to help achieve goals. English is increasingly needed in various fields such as Diplomacy, Bureaucracy, Trade and Tourism, which require direct contact with foreign parties and when tourists come to visit Indonesia. The reality on the ground in people's lives is that English has not shown adequate results, even though students have learned English from elementary, junior high, high school, vocational, and institutions. The mastery of English is a challenge for universities as a place to prepare to enter the workforce as professional academic candidates. To be able to enter easily in the world of work, higher education must equip graduates with good English skills.

Students' English ability is seen from the value of learning outcomes of courses is still low in speaking skills. Other facts show that curriculum implementation has not been fully integrated and specific to the needs of the workforce, and the English language taught is still common. While the demands and developments of the globalization era that English becomes an important requirement in educational activities and for special purposes or English for Specific Purposes (ESP). The learning process needs to be addressed especially for study program students who are not English Study Programs by using a more appropriate approach, design and learning by placing student needs as a central issue in the learning process. This is in line with the application of the English for Specific Purposes (ESP) based approach. Students become the main consideration in determining the process and direction of learning so as to achieve the objectives to be achieved. The implementation of the English for Specific Purposes (ESP) based approach will improving speaking skills in Room Division Management (RDM), and to meet the applicative needs that students must have is adjusted to the needs of the Industrial Business World (DUDI). Students are prepared to be able to keep up with the flow that is so fast developing. So that higher education must synergize with the Industrial Business World (DUDI). The goal of the business world and the synergistic industry world is to improve quality in accordance with the needs and demands of the workforce, so that graduates can easily enter the workforce, in this case specific English in certain professions is very good to be implemented.

\section{Methodology}

In this study using a descriptive method with a quantitative approach. As in the problem in this research is how the effectiveness English for Specific Purposes (ESP) to improving speaking skill in Room Division Management (RDM). Johson \& Johnson, 1998: Strevens in 
John \& Machando, 2000, Evans \& St. John in Kusni, (2005) suggested that: "English for Specific Purposes (ESP) as: "A movement based on the proposition that all language teaching should be tailored to the specific learning and language use needs of identified groups of student and also sensitive to the sociocultural context in which these students will be using English". Johnson \& Johson (1998) in Layla (2013) suggested that English for Specific Purposes (ESP) as: Language programmers designed for group or individuals who are learning with an identifiable purpose and clearly specifiable needs. English for Specific Purposes (ESP) as a recognizable activity within the broader professional framework of English language teaching, with implications for the design of syllabuses and materials as well as for the specification of areas of research". The concept of English for Specific Purposes (ESP) was also put forward by Evan \& St. John, Rahman, 2009 in Layla (2013) as follows: “...reason that the original pinnacle of development of the English for Specific purposes (ESP) movement resulted from General developments in the world economy in the 1950s and 1960s: the growth of science and technology, the increased use of English as the international language of science, technology and business, the increased economic power of certain oilrich countries and increased number of international students studying in UK, USA, and Australia".

Furthermore, the characteristics of English for Specific Purpose (ESP). John \& Marcando (2000) put forward the characteristics of English for Specific Purpose (ESP) as: 1) designed to meet needs of the learner;2) related to content (i.e. in its themes and topics) to particular disciplines, occupation, or activities;3)Centered on the language appropriate to these activities in syntax, lexis, discourse, semantics, and analysis of this discourse; 4) in contrast to "general English". Donough in Yaumi (2012) argues that" ESP courses are those where the syllabus and materials are determined in all essentials by prior analysis of the communication needs of the learner. So the ESP approach is a bottom-up approach. ESP refers to learning English which is oriented towards the special needs of learners according to the field of science and work. Material developed based on needs analysis. In other words, English in English for Specific Purpose (ESP) can support students' knowledge of the field of science in their chosen study program. Therefore, the preparation of curriculum both teaching material (RPS) and Syllabus must be in accordance with the needs of students in the study program being taught. There are three main points in designing the learning approach developed by Hutchinson: 1) Learning Centered course design; 2) Skill centered; 3) Learning centered. The process of learning approach or design that is learning centered course design aims to directly describe the relationship between needs analysis and content from English for Specific Purposes (ESP). So the ESP approach is a bottom up approach. ESP refers to learning English which is oriented towards the special needs of learners according to the field of science and work. The material developed is based on needs analysis, in other words, English in English for Specific Purposes (ESP) can support students' knowledge of the field of science in their chosen study program. Therefore, the preparation of curriculum both teaching material (RPS) and Syllabus must be in accordance with the needs of students in the study program taught. The data collection is the learning outcomes of English students A population of this study is tourism students in Batam Tourism Polytechnic (BTP). Meanwhile, the sample of this research has taken by purposive random sampling and involved about 41 tourism students.

\section{Result and Discussion}

The results of data processing from learning outcomes in speaking skills. Planning and implementation in the Room Division Management (RDM has fulfilled the contents in the 
learning curriculum. How student learning outcomes are seen from the final value of learning (UAS). Following are the results of processing student data grades.

Table 1. Descriptive Statistics

\begin{tabular}{llllllll}
\hline & N & Range & Minimum & Mean & & \multicolumn{2}{l}{$\begin{array}{l}\text { Std. } \\
\text { Deviation } \\
\end{array}$} \\
& Statistic & Statistic & Statistic & Statistic & Std. Error & $\begin{array}{l}\text { Statistic } \\
\text { Statistic }\end{array}$ \\
\hline Nilai RDM & 41 & 18 & 72 & 83.95 & .814 & 5.215 & 27.198
\end{tabular}

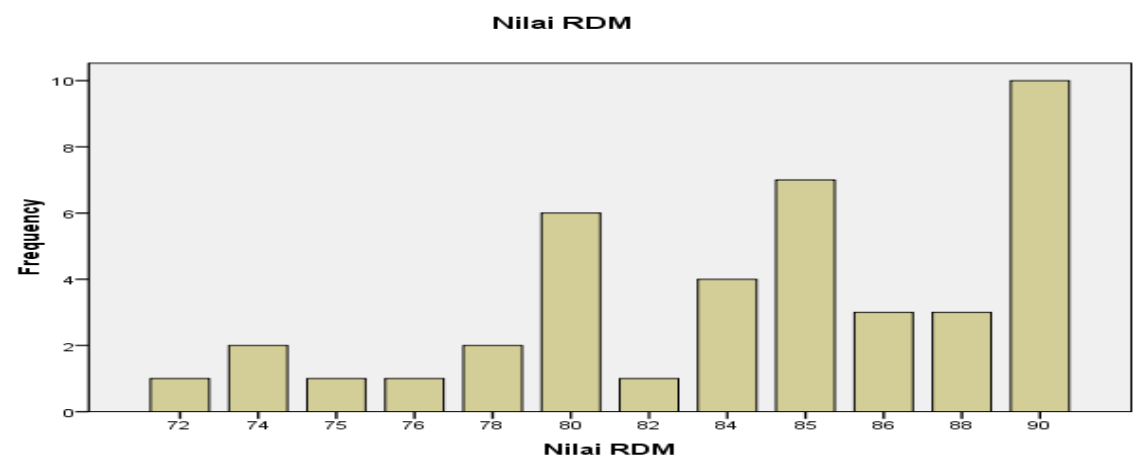

Fig.1. Students Grades Room Division Management (RDM)

The result presented by the study form quantitative data that are analyzed using SPPS 16 and also interview for add information. The results of interviews with lecture and tourism students Room Division Management (RDM).The Room Division Management (RDM) consists of two classes, each class totaling 18 students, and 23 students. So the total number of BTP 2019 in Room Division Management (RDM) Program students is 41. From the statistical processing of SPSS 16 in table 1 that $\mathrm{N}$ statistic is 41 , the range statistic is 18 , minimum statistic is 72 , mean statistic of 83.95 . There are 41 students, one student get 72 , two students get 74 , one student get 75 , one student get 76 , two student get 78 , sixth students get 80 , one student get 82 , fourth students get 84 , seven students get 85 , three students get 86 , three student get 88 , and there are ten students get 90 . So it can be concluded that student learning outcomes are very good, and meet the minimum completeness criteria (KKM) in learning. In the interview process, it was represented by 5 students. The results of the interview can be concluded that the planning of learning English has been based on English for Specific Purposes (ESP) and plans made by lecturers always provide and explain the curriculum that will be passed during one semester, and at the beginning of learning lecturers (sir) provide topics During one semester, several topics are presented, the final project is in the form of a project and presented at a meeting 13. Furthermore, the lecturer always explains the learning objectives to be followed at the beginning of the semester, so students know what the objectives of the material provided by the lecturer, and are able to apply in practice in the field. 


\section{Conclusion}

Implementation of learning in the Room Division Management (RDM), as the results of interviews with lecturers who teach English courses. He stated that the had an RPS that contained learning activities starting from the first activity, namely preliminary activities, core activities, and closing activities. Preliminary activities in learning begin with preparing students for learning by looking at absences. The lecturer explained the benefits of teaching materials in the world of work, and how the implications for the world tourism industry. The lecturer asks questions that relate previous knowledge to the material to be learned, and at the same time explains the learning objectives, competencies to be achieved, and the scope of the material. Then the last step in the preliminary activity is to explain the steps taken during the learning process. At the core activity, the learning process starts from giving the opportunity to students to find information through reading various literatures according to the theme of tourism learning, then presented in the class either individually or in groups. Furthermore, the lecturer gives the opportunity for students to carry out observations in accordance with the theme of tourism, and gives the opportunity for students to conduct experiments in accordance with the theme of tourism. tourism activities in the form of how to speak English with guests, serve guests and others. Furthermore, it gives an opportunity for students to do a case analysis in accordance with the theme, usually done when students present in class and analyzed together about something that is presented, and students explain the benefits of the theme created and report to the lecturer the results of the presentation. Furthermore, lecturers provide opportunities for students to find generalizations in accordance with the theme of tourism, and students identify problems in accordance with the theme of tourism. Finally, in the core activity is the lecturer giving feedback both verbally or verbally on student success, and provide direct motivation in class to students who have not participated actively. Lecturers in the learning process are only as facilitators.

The learning process in the closing activity begins to make conclusions together with students, reflect on the activities that have been carried out, feedback on the process and learning outcomes in the form of results from UTS. Furthermore, the lecturer plans follow-up activities (remedial, enrichment either individual assignments or group assignments. It can be concluded that by using the ESP approach in learning English, the results of students' speaking skills improve and effective in the learning process. The value of English courses for Room Division Management (RDM) students is in the form of grades obtained from studying in class, with a standard score of 70. Room Division Management Study Program (RDM) BTP has the highest score of 90 , and the lowest value obtained by students is 72 , with this the students have fulfilled KKM in learning.

\section{References}

[1] Ajisoko.(2018). Develoving Instructional Design Of English For Specific Purposes In The English Educational Study Program Borneo University Of Tarakan. Jurnal Edukasia, Volume 5,Nomor 2,tahun 2018. E-ISSN:2654-329X.Tersedia Online: http://ojs.borneo.ac.id/ojs/index.php/JED/article/view/423.

[2] Astawa. (2011). Pengajaran "English For Guiding” Berbasis Pendekatan Sosiokultural. Jurnal Santiaji Pendidikan, 2011, 1 (2): 170-178. ISSN 2087-9016.

[3] Askar. (2005). Improving ESP Course Design at Indonesia Universite: A collective Collaborative Model.Yogyakarta: Proceeding pada internasional TEFLIN Conference .Ahmad Dahlan University. 
[4] Battacherjee, A. (2012). Social Science Research: Principles, Methods, and Practices. First published 2012 ISBN-13.

[5] Benavent, TG. (2011). Use of Authentic Materials in the ESP Classroom. Encuentro 20, 2011. ISSN 1989-0796. Chen, Y. (2006). From common core to specific. The Asian ESP Journal, 1, 2450 .

[6] Dudley-Evans, Tony. (1998). Developments in English for Specific Purposes: A multidisciplinary approach. Cambridge: Cambridge University Press.

[7] EKO M, Andreas. (2016). Pengembangan Bahan Ajar Bahasa Inggris Berbasis Kompetensi Kerja Untuk Mempersiapkan Peserta Didik Menempuh On The Job Trining di Bagian Front Office Hotel (Studi Pengembangan di International Hotel Management School). Masters thesis, Universitas Sebelas Maret. Tersedia Online: https://eprints.uns.ac.id/28840/).

[8] Far, Mohammad M. (2008). On the Relationship Between ESP \& EGP: A General Perspective. English for Specific Purposes World Issue I (17), Volume 7,2008) http://www.espworld.info/Articles_17/PDF/On\%20the\%20Relationship\%20between\%20ESP\%20 $\% 26 \% 20$ EGP\%20\%28Mohseni\%20Far\%29.pdf.

[9] Gao, J. J. (2007). Designing an ESP course for Chinese university students of business. The Asian ESP Journal, 3(1), 98-107.

[10] Gede. (2014). Identifikasi Materi Ajar Keparawisataan Serta Relevansinya dengan materi Ajar Bahasa Indonesia Ragam Keparawisataan Untuk Siswa Kelas X SMK Program Keahlian UPW Di Kota Denpasar.Seminar Nasional Riset Inovatif II, Tahun 2014.ISSN:2339-1553.

[11] Ghozali, Imam. (2011). Pengembangan Buku Teks Bahasa Inggris Integratif untuk Sekolah Menengah Kejuruan: Penelitian Pengembangan Pendidikan di Sekolah Menengah Kejuruan Jurusan Usaha Jasa Pariwisata di Yogyakarta. PhD thesis, Universitas Sebelas Maret.

[12] Hossain. (2013). ESP Needs Analaysis for Enginering Students: A learner Centered Approach. Journal of PU. Part B.Vol 2.No 2 July 2013.pp 16-26. Presidency University.ISSN 2224-7610.

[13] Hutchinson,T \&Waters, A.(1987). English for Specific Purposes. Cambridge: Cambridge University Press.

[14] Ismailia, dkk. (2015). Pengembangan Program Pelatihan Pra-Magang Mahasiswa Program Studi Bahasa Inggris Politeknik Negeri Jember. Jurnal Inovasi Teknologi Pendidikan. Volume 2,

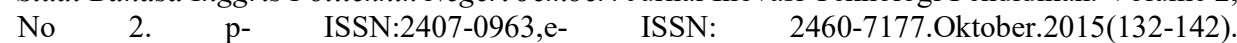
Online:http://journal.uny.ac.id/index.php/jitp.

[15] Imrotus. (2016). Pengembangan Model Kurikulum Pendidikan Bahasa Inggris Berbasisi KKNI.Konstruktivisme, Vol 8.No1, januari 2016. P-ISSN 1979-9438,e-ISSN:2445-2355.

[16] Johson, M.A.,\& Machando, P.D.2000. English Specififc Purposes:Tailoring Courses to student Needs and to the Outside World. Dalam Makalah Teaching English as a second or Foreign Language.

[17] Kusumaningputri. (2010). English for Specific purpose (ESP) di Universitas Negeri Jember: Tantangan dan Solusi Jurnal Pengembanagan Pendidikan.Vol. 1. No.1. ISSN: 14138876. Jember. LP3 UNEJ.

[18] Kurniawaty, Layla. (2013). English for Specific Purpose (ESP) Teachimg Aproach For Student. (Praja) Of Public Administration Institute Of Home Affairs (IPDN). Tersedia ONLINE (httpicerd2018.conference.upi.eduwp-contentuploadssites30201812fullpaperlayla-Kurniawati.pdf).

[19] Khan dkk. (2011). Need Analysis of English for Occupational and Specific Purposes. International Journal of Social Sciences and Education. Vol.1 Issue 4 Oct 2011.

[20] Lo, Y. F., \& Sheu, C. M. (2008). The design, implementation, and evaluation of an English tour guide project. The Asian ESP Journal, 4(2), 79-94.

[21] Lo, Yi-Hsuan Gloria. (2011). ESP versus EGP: A case study of an ESP program for vocational high school students of Tourism. TIESPJ, Vol. 3: 2, 2011

[22] Melinda. (2013). ESP Dalam Pembelajaran Bahasa Inggris Di PTAI. Jurnal Ijtimaiyya.Vol 6.No.2. Agustus 2013.

[23] Paniya. (2008). Designing an ESP Course for Indonesian Vocational College Students. Ragam Jurnal Pengembangan Humaniora Vol. 8 No. 1, April 2008. 
[24] Rethy F. Lioew. Peran LPTK Dalam Pengembangan Pendidikan Vokasi di Indonesia. Seminar Internasional, ISSN 1907-2066.

[25] Robertson, P. (2005). How to become a flight attendant in Korean: English skills. The Asian ESP Journal, 1(3), Retrieved July 10, 2011 from http://www.asian-espjournal.com/December_2005_pr.php.

[26] Sugiyono. (2012). Metode Penelitian Kuantitatif, Kualitatif, Dan R\&D.Bandung: Alfabeta.

[27] Sujana. Dkk. (2010). Landasan Filosofis dan Teoritis Standar Bahasa Inggris Dalam KTSP Dan Tantangan Kurikulum LPTK Bahasa Inggris. Jurnal Linguistik, sastra dan budaya (LISDAYA).jpbs fkip unram. Vol, 6.No.1.2010.

[28] Vicic, P. (2011). Preparing Materials for ESP Teaching. Inter Alia 2, 107-120.

[29] Simion, MO. (2012). The Importance of Teaching English in the Field of Tourism Universities. Economy Series, Issue, 2/2012.

[30] Tarigan. (2008). Berbicara Sebagai Suatu Keterampilan Berbahasa. Angkasa: Bandung.

[31] Ulfa, K. (2015). Designing ESP Materials for Tourism Students of Akademi Pariwisata Medan. Pelita Informatika Budi Darma, Volume: IX, Nomor: 22. Maret, 2015.

[32] Unal, Abdulkadir. (2014). The Probelms Encountered in English for Specific Purpose: Business Department Case. The Clute Institute International Academic Conferences. Munich, Germany. 